\title{
POST-COMPLAINT DISCOVERY IN ADMINISTRATIVE PROCEEDINGS: THE FTC AS A CASE STUDY*
}

\author{
JoEL P. BenNetT**
}

The FTC's post-complaint discovery rules have been the subject of considerable litigation. In this Article, Mr. Bennett analyzes the problems which have arisen under the current FTC rules and concludes that the FTC should adopt the federal discovery rules. As this Article went to press, the FTC circulated for comment new discovery rules which are quite similar to the federal rules. They are reprinted at 40 Fed. Reg. $15239-45$ (Apr. 4, 1975).

\section{INTRODUCTION}

In these times of increasingly protracted and complex administrative adjudicatory proceedings, ${ }^{1}$ the proper and efficient use of pretrial discovery to develop relevant evidence becomes a critical factor in minimizing delay both in the pre-trial and trial stages of a proceeding. It is the purpose of this Article briefly to review the historical background of discovery in civil and administrative proceedings, to compare discovery under the Federal Rules of Civil Procedure with discovery under the Federal Trade Cominission's (FTC) Rules of Practice, to examine the evolution of post-complaint ${ }^{2}$ dis-

* The opinious expressed in this Article represent solely the views of the author. They are not inteuded to be, and should not be construed as, represeutative of official Federal Trade Commission policy.

** Attorney, Division of Marketing Practices, Bureau of Consumer Protection, Federal Trade Commission, Washington, D.C. Meinber, District of Columbia Bar; A.B. 1968, Brown University; J.D. 1972, Georgetown University Law Center.

THE FOLLOWING CITATIONS WILI BE USED IN THIS ARTICLE:

Lewis, Discovery Teclniques and the Protection of Confidential Data in FTC Proceedings, 21 AD. L. REv. 457 (1969) [hereinafter cited as Lewis];

C. Wright \& A. Mitler, Federal Practice and Procedure (1970) [hereinafter cited as C. Wright \& A. Miller].

1. E.g., United States v. IBM, No. 69 Civ. 200 (S.D.N.Y., filed Jan. 17, 1969) (pretrial inemoranda not filed until Oct. 21, 1974, nore than a inillion docunients involved in discovery, 600 witnesses listed for trial) (for a summary of developinents in this case, see 5 Trade Reg. Rep. If 45,070, at 53,219-20); Exxon Corp., No. 8934 (F.T.C., filed July 18, 1973) (eight respondents, seventeen Commission attorneys assigned to the case, FTC counsel's discovery expected to eucompass millions of documents and hundreds of depositions) (for the developinents in this case, see 3 TRADE REG. REP. ITा $20,388,20,400,20,527,20,583,20,599,20,675$ ).

2. For those unfamiliar with administrative proceedings, the use of the terms "precomplaint" and "post-complaint," as opposed to "pre-trial," in this context may be confusing. The terms are used to differentiate between an agency's discovery in the investigative stage of a proceeding before a deternination to issue a complaint is made (precomplaint discovery), and the discovery engaged in by all parties once a coinplaint has issued and the inatter is in the formal adjudicative stage (post-complaint discovery). 
covery under the FTC's rules and the judicial decisions interpreting those rules, and finally, to evaluate the adequacy of those rules in light of complex and protracted FTC cases such as the one presently pending against the eight leading oil companies. ${ }^{3}$

\section{Historical Background of Civil and AgEncy Discovery}

Prior to the promulgation of the Federal Rules of Civil Procedure in $1938,{ }^{4}$ pre-trial discovery in federal civil proceedings was quite limited. The pleadings served as virtually the only basis of preparation for trial under the procedures followed in the federal courts before the adoption of the new federal rules. Apparently the philosophy of these earlier procedures was that hitigation is partly a contest of wits and that one contestant should not be compelled to supply his opponent any information. ${ }^{5}$ Thus, before 1938, there was no right to examine opposing parties or witnesses before trial in actions at law in the federal courts, except for the purpose of preserving proof. Discovery occurred only incidentally to this purpose. ${ }^{6}$ Only in equity proceedings was discovery allowed, and it was cumbersome and restrictive. ${ }^{7}$

Therefore, it is not surprising that the liberal pre-trial discovery introduced in 1938 was hailed by the Supreme Court as "one of the most significant innovations of the Federal Rules of Civil Procedure."8 No longer were parties dependent upon pleadings for issue-formulation and fact-revelation. The function of pleadings was relegated to that of giving the opposing party notice, while the new rules "[invested] the deposition-discovery process with a vital role in the preparation for trial."

The discovery devices which the new rules established are depositions, ${ }^{10}$ written interrogatories, ${ }^{11}$ production of documents and tan-

Compare 16 C.F.R. $\$ \S 2.1-.35$ (1974) (FTC rules for pre-complaint discovery) with id. $\S \S 3.1-.72$ (FTC rules for post-complaint discovery).

3. Exxon Corp., No. 8934 (F.T.C., filed July 18, 1973).

4. The original Federal Rules of Civil Procedure were promulgated by the Supreme Court under authority of the Act of June 19,1934, ch. 651, 48 Stat. 1064, as amended, 28 U.S.C. $\$ 2072$ (1970), and became effective on Sept. 16, 1938. Rules of Civil Procedure for the United States District Courts, 28 U.S.C. App. 7729 (1970). See Rules of Civil Procedure for the District Courts of the United States, 308 U.S. 645 (1938).

5. 8 C. WRIGHT \& A. MILLER $\$ 2001$, at 14.

6. Id. $\$ 2002$, at $21 \mathrm{n} .26$.

7. Id. $\S 2002$, at 21 .

8. Hickman v. Taylor, 329 U.S. 495, 500 (1947).

9. Id. at 501.

10. Fed. R. Civ. P. 30.

11. FED. R. CTV. P. 33. 
gible things, ${ }^{12}$ physical and mental examinations, ${ }^{13}$ and requests for admissions. ${ }^{14}$ Of all these devices, the mightiest weapon in the ar-' senal may well be the deposition. ${ }^{15}$ In federal courts, depositions are by far the most widely used of the discovery devices. ${ }^{16}$

Since their enactment, the rules have been liberalized through amendment. In 1946, Rule 26 was amended ${ }^{17}$ to indicate that the scope of discovery is not limited to evidence admissible at trial but also encompasses any relevant inquiry calculated to lead to admissible evidence. ${ }^{18}$ In 1970 , Rule 34 was amended ${ }^{19}$ to eliminate the requirement of a court order and a showing of good cause by the party seeking the production of documents. This amendment put an end to needless litigation over the meaning of "good cause."20

Thus, the Federal Rules of Civil Procedure created a discovery system designed to operate on the mitiative of the parties and, where possible, without court intervention. In contrast, the discovery procedures of the federal administrative agencies which engage in civil litigation $^{21}$ similar to that conducted under the federal rules are much more limited ${ }^{22}$ and often require the direct involvement of the administrative law judge at each step in the discovery process. ${ }^{23}$

All federal agencies which conduct civil litigation have the power to discover facts prior to an adjudicatory hearing through their power to conduct investigations. They derive this pre-complaint, investigatory power from their enabling acts. ${ }^{24}$ But it is the availability of

12. FED. R. Civ. P. 34.

13. FED. R. CIV. P. 35.

14. FED. R. Crv. P. 36.

15. See 8 C. WRIGHT \& A. MILLER $\$ 2163$, at $486-87$.

16. W. Glaser, Pretrial Discovery and the Adversary System $52-54$ (1968); 8 C. WRIGHT \& A. MILLER § 2163, at 486-87.

17. Amendments to Rules of Civil Procedure, 329 U.S. 839, 854 (1946), amending Fed. R. Civ. P. 26, 308 U.S. 694 (1938).

18. See 4 J. MOORE \& J. LuCAS, MoORE's Federai Practice $\prod$ 26.56, at 116 (1974).

19. Amendments to Rules of Civil Procedure, 398 U.S. 977, 997-98 (1970), amend. ing Fed. R. Civ. P. 34, 329 U.S. 857 (1946).

20. See 8 C. WRIGHT \& A. MILLER $\S 2205$, at $602-03$.

21. The agencies are the Civil Aeronautics Board ( $\mathrm{CAB}$ ), the Federal Communications Commission (FCC), the Federal Power Commission (FPC), the Federal Trade Commission (FTC), the Interstate Commerce Commission (ICC), the National Labor Relations Board (NLRB), and the Securities and Exchange Commission (SEC).

22. See $1 \mathrm{~K}$. Davis, Administrative LaW Treatise $\S 8.15$, at 588 (1958).

23. See text accompanying note 109 infra.

24. Federal Trade Commission Act $\S \S 6(a), 9,15$ U.S.C. $\S \S 46(a), 49$ (1970) (FTC); Securities Exchange Act of 1934, $\S \S 21$ (a)-(b), 15 U.S.C. $\$ \S 78 u(a)-(b)$ (1970) (SEC); Federal Power Act $\S 3$ 307(a)-(b), 16 U.S.C. $\$ \S 825 f(a)-(b)$ (1970) (FPC); Labor-Management Relations Act $\$ 11(1), 29$ U.S.C. $\S 161(1)$ (1970) (NLRB); Federal Communications Act of 1934, $\S \S 403$, 409(b), 47 U.S.C. $\S \S 403$, 
mutual, post-complaint discovery that is the subject of this Article, and to determine its parameters, the Administrative Procedure Act ${ }^{25}$ (APA) and the agencies' rules of practice and procedure must be ex. amined.

Although the APA does not provide for mandatory post-complaint discovery, the need for an application of the basic principles underlying discovery was recognized in one of the reports that led to the enactment of the APA. ${ }^{20}$ In the APA itself, section 6(c) provides that "subpenas authorized by law shall be issued to a party on request and, when required by rules of procedure, on a statement or showing of general relevance and reasonable scope of the evidence sought"; ${ }^{27}$ and section 12 inakes the evidential and procedural privileges of the APA applicable to both agencies and parties. ${ }^{28}$ The agencies' rules of practice, however, typically confined the availability of their postcomplaint subpoenas to the actual liearing while allowing their staffs to use pre-complaint subpoenas for investigation. ${ }^{29}$ This situation led to a critical examination of discovery im agency adjudication by various study commissions and commentators in the early $1960 \mathrm{~s}^{\mathrm{s}}{ }^{30}$ One of the most significant recommendations to come out of all of this analysis was that of the temporary Administrative Conference of the Umited States, whicl approved in principle the application of discovery rules to federal administrative adjudicatory proceedings. ${ }^{31}$ Equally significant was the Report of the Conference's Committee on

409(b) (1970) (FCC); Interstate Commerce Act $\$ \S 12,13,49$ U.S.C. $\$ \S 12,13$ (1970) (ICC); Federal Aviation Act of 1958, $\S$ 1002(b), 1004(b), 49 U.S.C. $\S \S 1482$ (b), 1484(b) (1970) (CAB).

25. 5 U.S.C. $\$ \S 551$ et seq. (1970).

26. See UntTed States Attorney General's Comm. on Adminstrattve ProceDURE FINAL REPORT 64 (1941). By noting that better results would be obtained if the parties were fully informed before the hearing, the Report recognized the basic argnment in favor of discovery, even though it focused on the use of pre-trial conferences and stipulations.

27. 5 U.S.C. $\$ 555(d)$ (1970) (emphasis added).

28. Id. $\$ 559$.

29. See, e.g., 14 C.F.R. $\$ 302.19$ (a) (1974) (CAB); 17 C.F.R. $\$ 201.14$ (b) (1974) (SEC). See also E.B. Muller \& Co. v. FTC, 142 F.2d 511, 518-20 (6th Cir. 1944); Joseph A. Kaplan \& Sous, Inc., 57 F.T.C. 1537, 1538 (1960); Standard Motor Products, Inc., 50 F.T.C. 624 (1954).

30. E.g., Administrative Conference of the United States, Final Report, in S. Doc. No. 24, 88th Coug., 1st Sess. (1963); Berger, Discovery in Administrative Proceedings: Why Agencies Should Catch Up With the Courts, 46 A.B.A.J. 74, 75-76 (1960); Kaufman, Have Administrative Agencies Kept Pace With Modern Court-Developed Teclniques Against Delay?-A Judge's View, 12 AD. L. Rev. 103 (1960).

31. Recommendation No. 30 , in S. Doc. No. 24, supra note 30, at 37 . For a detailed discussion of the Conference's 1970 recommendations, see Tomlinson, Discovery in Agency Adjudication, 1971 DUKE L.J. 89. 
Compliance and Enforcement Proceedings urging agencies to adopt as much of the discovery part of the Federal Rules of Civil Procedure as seemed appropriate. ${ }^{32}$

The recommendation produced responses ranging from adoption of rules very close to the discovery procedures under the Federal Rules of Civil Procedure ${ }^{33}$ to no change at all. ${ }^{34}$ One year before the Conference's recommendation, the FTC, as part of a general overhaul of its procedures, substantially liberalized its discovery rules. ${ }^{35}$ Yet, even with two subsequent (1963 and 1967) further liberalizations, the FTC discovery rules are still a long way from the discovery provisions of the federal rules. ${ }^{36}$

\section{Current fTC Post-Complaint Discovery Rules Compared with the Federal Rules of CivIL Procedure}

Prior to 1961 , trial by interval was the method used by the FTC in its adjudications; the final record was compiled through a series of liearings held in various locations at intervals of time. ${ }^{37}$ When the change was made to continuous hearings, in which the entire trial was conducted without any substantial interruptions, the parties needed more extensive post-complaint discovery than had been necessary under the former procedure. ${ }^{38}$ This was particularly true of the respondents, usually businesses, who unlike the FTC had no pre-

32. Report of the Committee on Compliance and Enforcement Proceedings in SuPport of ReCommendation 30, in S. Doc. No. 24, supra note 30 , at 115 . Of course, the Federal Rules of Civil Procedure are not applicable to administrative proceedings. Ash Grove Cement Co., 77 F.T.C. 1660, 1661 (1970); 1 K. Davss, supra note $22, \S 8.15$, at 588 .

33. The FCC rules closely approximate the federal rules. Compare FED. R. Crv. P. 26-37 with 47 C.F.R. $\$ \S 1.311-.325$ (1974).

34. See Tomlimson, supra note 31 , at 90 . For a description of the discovery practices of the NLRB, FTC, CAB, and FPC as of 1966, see Manoli \& Joseph, The National Labor Relations Board and Discovery Procedures, 18 AD. L. Rev. 9 (Winter-Spring, 1966); Mezines \& Parker, Discovery Before the Federal Trade Commission, 18 AD. L. Rev. 55 (Winter-Spring, 1966); Maurer, Use of Discovery Procedures Before the C.A.B., 18 AD. L. REv. 157 (Winter-Spring, 1966); Ross, Discovery and the Federal Power Commission, 18 AD. L. Rev. 177 (Winter-Spring, 1966).

35. See Tomlinson, supra note 31 , at 90.

36. Compare Fed. R. Civ. P. 26-37 with 16 C.F.R. $\$ \$ 3.31-.37$ (1974). See Dixon, Significant New Commission Developments, 23 ABA ANTITRUST SECTION ReP. 50, 59 (1963); Lewis 458-60; Mezines \& Parker, supra note 34, at 61; Note, Discovery in Federal Administrative Proceedings, 16 Stan. L. Rev. 1035, 1051-52 (1964). See also Gellhorn, The Treatment of Confidential Information by the Federal Trade Commission: Pretrial Practices, 36 U. CHI. L. Rev. 113, 142-46 (1968).

37. See Lewis 457.

38. See L.G. Balfour Co., 62 F.T.C. 1541 (1963); Joseph A. Kaplan \& Sons, Inc., 57 F.T.C. 1537,1539 (1960). 
complaint discovery. Thus, the FTC's post-complaint discovery procedures were born in 1961 as a by-product of the change from trial by interval to continuous hearimgs.

Although some provisions of the FTC rules correspond closely to the federal rules, ${ }^{39}$ there remains a fundainental difference in approach between FTC discovery and discovery under the federal rules. Under the federal rules, the party seeking discovery need only file notice of his intent, ${ }^{40}$ and judicial imtervention occurs only if the party against whom discovery is sought resists. ${ }^{41}$ If there is a contest, the resisting party has the burden of showing good cause why the discovery should not take place. ${ }^{42}$ Under the FTC rules, however, apphication inust be nnade to the administrative law judge each time a deposition or subpoena for documents is sought. ${ }^{43}$ Furthermore, the party seeking a deposition, either oral or by written interrogatory, must show that the deposition is necessary for purposes of discovery and that the information sought could not be obtained by voluntary methods; ;4 a party seeking a subpoena nust show the general relevance of the documents and the reasonableness of the scope of the subpoena. ${ }^{45}$

In addition to this fundainental difference, there are several specifics in which the two sets of discovery provisions differ. For example, there is no FTC rule which provides for the answering of written interrogatories directed toward parties who are not natural persons. The significance of this omission is that FTC depositions by written interrogatories under FTC Rule 3.33 cannot be addressed to a party corporation with the requirement that its officer or agent furnish such information as is available to the corporation. Such information can be compelled when Federal Rule 33 is in effect. ${ }^{46}$

Another area of contrast between the two sets of rules is that of sanctions for unjustified failure to comply with lawful discovery requests. Under the federal rules, if the recalcitrant party fails to heed

39. For example, the provisions as to requests for admissions of facts and documents are quite similar. Compare Fed. R. Civ. P. 36 with 16 C.F.R. \$ 3.31 (1974) (FTC Rule 3.31).

40. Federal Rule $30(\mathrm{~b})$ requires a party desiring to take a deposition to provide notice to every other party to the action. Federal Rule 33 provides for service of interrogatories upon a party. Such service provides notice to the party.

41. FED. R. CIV. P. 26(c); see 8 C. WRIGHT \& A. MilleR $\$ 2035$, at 261.

42. Fed. R. Civ. P. 26(c); see 8 C. WRIGHT \& A. MILLER $\$ 2035$, at 264-66.

43. 16 C.F.R. $\S \S 3.33,3.34$ (1974) (FTC Rules 3.33 and 3.34).

44. $I d . \S 3.33(\mathrm{a})$.

45. Id. $\$ 3.34(\mathrm{~b})(1)$.

46. See Fed. R. Crv. P. 33(a). 
the judge's order, that party may have to bear adverse inferences, the striking of claims or defenses, default judgment, contempt citations, and/or expenses. ${ }^{47}$ The FTC rules do not make default judgment and the bearing of expenses express sanctions, although the administrative law judge is empowered to "take such action . . . as is just." 48 More important, perhaps, is the fact that these sanctions are used in federal court proceedings while they do not appear to be used in FTC proceedings. ${ }^{49}$

It is apparent that the most significant difference between discovery under the federal rules and under the FTC rules is that under the latter scheme, the party seeking discovery bears the burden of going to the admimistrative law judge for every deposition and subpoena duces tecum and justifying its issuance. An examination of the leading cases involving the FTC rules since 1967 will highlight some of the difficulties of practice under them.

\section{FTC Discovery in Practice: The Case Law}

A number of problems have arisen concerning the interpretation of the FTC's discovery rules as they have stood since 1967. One of the first problems, and one which has taken the Commission seven years to put to rest, was that of the proper bounds of FTC counsel's post-complaint discovery in relation to the pre-complaint investigation. This problem surfaced in All-State Industries, Inc., ${ }^{50}$ in which the Commission quashed the hearing examiner's order permitting the inspection and copying of an exceedingly broad class of docuinents, ${ }^{51}$ stating that "the [discovery] rules are not intended to provide for comprehensive post-complaint investigation, but only postcomplaint discovery." "52 Respondents have seized upon this language to attack the use of discovery by FTC counsel on the ground that the discovery rules are being used as a means of conducting post-complaint investigation.

The Commission could have easily based its decision in All-State

47. Fed. R. Civ. P. 37.

48. 16 C.F.R. $\$ 3.38$ (a) (1974) (FTC Rule 3.38(a)).

49. See 4A J. MOORE \& J. LUCAS, supra note $18, \mathbb{1} 37.03$.

50. 72 F.T.C. 1020 (1967).

51. See id. at 1024-25.

52. Id. at 1024 (emphasis added). The Commission's tough stance in All-State may have been precipitated by the drubbing it took in United States v. Associated Merchandising Corp., 261 F. Supp. 553 (S.D.N.Y. 1966), wherein subpoena enforcement was denied in part because of the dragnet approach toward the requested documents. Id. at 556. See also Elman, Administrative Reform of the Federal Trade Commission, 59 GEO. L.J. 777, 815-20 (1971). 
on the very terms of FTC Rule 3.34(b)(1), whereby the moving party has the burden of "showing . . . the reasonableness of the scope of the subpoena," 53 since the subpoena in question was very wide-ranging. The Commission's failure to tie its result to that rule gave respondents an additional, although tenuous, ground for opposing FTC counsel's discovery requests. Apparently attempting to limit the All-State language, the Commission issued a supplemental opinion $^{54}$ in the case in which it stated that the earlier opinion was not intended "to change the standards which the Rules of Practice establish for dealing with applications for discovery"55 and that respondents do not have "the right to put into litigation the adequacy of the precoinplamt investigation conducted by the Commission or its staff." $"$ os

Nevertheless, the All-State argument has been raised, unsuccessfully, in case after case through 1974. ${ }^{57}$ The Commission, however, has very recently announced the abandonment of the All-State requirement that investigatory work be complete before a complaint is issued. $^{58}$ Thus, after seven years of appeals and delays in which no subpoena, other than the one in All-State, has been demied on the ground specified in the All-State opinion, this Pandora's box hopefully has been closed.

A second issue which has arisen under the present FTC rules is whether depositions are available only to preserve evidence or for discovery as well. The following language in FTC Rule 3.33(a) has raised this issue:

Such order [for a deposition] may be entered upon a showing that the deposition is necessary for purposes of discovery, and that such discovery could not be accomplished by voluntary methods. Such order [for a deposition] may also be entered in extraordinary circumstances to preserve relevant evidence upon a showing that there is substantial reason to believe that such evidence could not be presented through a witness at the hearing. ... [A deposition] slould not be ordered to obtain

53. 16 C.F.R. $\S 3.34(b)(1)$ (1974).

54. 74 F.T.C. 1591 (1968).

55. Id. at 1592.

56. Id.

57. E.g., FTC v. Browning, 435 F.2d 96, 103 (D.C. Cir. 1970); Food Fair Stores, Inc., 3 CCH TRADE REg. Rep. đI 20,579 (F.T.C., April 23, 1974); Order Quashing Investigational Subpoena, Exxon Corp., No. 8394 (F.T.C., July 27, 1973).

58. 702 BNA ANtTrRust \& Trade Reg. Rep. A-11 (Feb. 25, 1975). This announcement was foreshadowed by the statement in a recent case that future appeals predicated on the alleged inadequacy of pre-complaint investigation might constitute misuse of the appeal process to delay adjndication. See Food Fair Stores, Inc., $3 \mathrm{CCH}$ TrADE REg. REP. I 20,579 (F.T.C., Apr. 23, 1974). 
evidence from a person relating to matters with regard to which he is expected to testify at the hearing, or to obtain evidence which there is reason to believe can be presented at a hearing without the need for deposition, or to circumvent the orderly presentation of evidence at the hearing. ${ }^{59}$

On its face, it seems that the rule refers to two kinds of depositions: those for discovery and those to preserve evidence, ${ }^{60}$ and that the restriction concerning potential witnesses only applies to the latter kind. However, respondents in two recent cases, General Motors Corp. ${ }^{61}$ and The Great Atlantic \& Pacific Tea Co., ${ }^{62}$ and a hearing examiner in an earlier case, Koppers Co. ${ }^{63}$ have read the rule as prohibiting the deposing of any person who is expected to testify at the trial. ${ }^{64}$ Fortunately for those who believe in the usefulness of depositions in FTC practice, respondents' arguments in those two cases and the hearing examiner's imterpretation of FTC Rule 3.33(a) have been rejected. ${ }^{65}$

Shortly after FTC Rule 3.33(a) became effective, the hearing examiner in Koppers. demied respondent's apphication to take depositions for discovery in part on the ground that "all persons whose depositions are sought are expected to testify ...."66 On appeal of this ruling, the Commission noted that the limiting language of FTC Rule 3.33(a) refers only to depositions "to obtain evidence," and distinguished depositions "to obtain evidence" from depositions "for pur-

59. 16 C.F.R. $\$ 3.33$ (a) (1974).

60. Depositions to preserve evidence are also provided for under Federal Rule 27.

61. Memorandum in Support of Motion for Modification of Order Granting Complaint Counsel's Request to Take Depositions of Employees of Respondent General Motors Corporation for Purposes of Discovery at 16-18, General Motors Corp., No. 8907 (F.T.C., filed June 18, 1973). The General Motors case has been settled. General Motors Corp., No. 8907 (F.T.C., Jan. 10, 1975).

62. Request for Permission to Appeal at 3-4, 8-9, The Great Atlantic \& Pacific Tea Co., No. 8916 (F.T.C., filed July 26, 1973). The administrative law judge's decision has been issued in this case but discovery was not an issue. The Great Atlantic \& Pacific Tea Co., No. 8916 (F.T.C., Jan. 24, 1975).

63. See 74 F.T.C. 1571 (1968). The case involved the alleged monopolization by Koppers Company of the market for resorcinol.

64. Even one commentator shares this view. See Schniderman, Securing Adequate Discovery in Administrative Proceedings,:25 AD. L: Rev. 167, 171 (1973).

65. Demial of Request for Determination Pursuant to Rule 3.23(b) Permitting Interlocutory Appeal in Commission's Discretion at 3, The Great Atlantic \& Pacific Tea Co., No. 8916 (F.T.C.; Aug. 9, 1973); Order Denying Respondent's (General Motors Corpo-: ration's) Motion for Modification of Order-Granting Complaint Counsel's Request to Take Depositions of Employees of Respondent. General Motors Corporation for Purposes of Discovery at 4, General Motors Corp., No. 8907 (F.T.C., June 22, 1973); Koppers Co., 74 F.T.C. 1571, 1572-73 (1968).

... 66: :74 F.T.C. at -1571: . 
poses of discovery."07 Thus, the Commission held that FTC Rule 3.33(a) provides for depositions both to preserve evidence and for purposes of discovery and that a deposition for discovery was not to be denied merely because the deponent was expected to appear as a witness. ${ }^{88}$

The application of the restriction on depositions to preserve evidence to all depositions, even those requested for discovery purposes only, would have had the anomalous result of making depositions unavailable merely because the deponent was expected to testify at trial. Each party would then be denied advance knowledge of the testimony of the other party's witnesses, and effective cross-examination would be nearly impossible. ${ }^{60}$ In addition, the element of surprise would once again become an effective trial weapon. Therefore, although the wording of FTC Rule 3.33(a) is not free of ambiguity, the Koppers holding was mandated by a common sense view of the evolving nature of FTC discovery.

Despite the seemingly clear holding in Koppers, respondents in General Motors and $A \& P$ still argued that the restrictions of FTC Rule 3.33(a) apply to all depositions. ${ }^{70}$ Administrative Law Judge Barnes in General Motors correctly identified the depositions sought as being for discovery and therefore held that the question of whether deponents were potential witnesses was immaterial. ${ }^{71}$ Administrative Law Judge Hanscom in $A \& P$ took a different tack, upholding FTC counsel's right to depose respondent's eniployees to determine whether to call thein as witnesses. ${ }^{72}$ Although both judges clearly

67. Id. at 1572-73. The Commission read the limiting language of FTC Rule 3.33(a) as a logical extension of FTC Rule 3.33(f)(2), which allows the contents of depositions to constitute evidence only in special cases, see 16 C.F.R. $\$ 3.33(f)(2)$ (1974). 74 F.T.C. at 1572-73. Since FTC Rule 3.33(f)(2) prolibits the use of depositions as evidence when the deponent is able to testify, the Commission reasoned that the restriction in FTC Rule 3.33(a) was merely meant to prohibit the taking of useless depositions to preserve evidence. Id.

68. 74 F.T.C. at $1572-73$.

69. See id. at 1573. The right to effective cross-examination is embodied in the APA. See 5 U.S.C. \& 556(d) (1970). See alsó Pacific Molasses Co. v. FTC, 356 F.2d 386, 390 n.12 (6th Cir. 1966).

70. See authorities cited in notes 61-62 suprá.

71. Order Denying Respondent's (General Motors Corporation's) Motion for Modification, supra note 65 , at 4 . Judge Barnes wrote, "The fact that one or more of the proposed deponents may be called to testify in the proceeding is not a basis, in and of itself, to preclude the taking of discovery depositions." Id.

72. Ruling Granting Motion of Complaint Counsel for an Order Authorizing Depositions of Employees of A \& P at 4-5, The Great Atlantic \& Pacific Tea Co., No. 8916 (F.T.C., July 16, 1973). A \& P's counsel even went so far as to suggest that Koppers applied only to a respondent's constitutional right to cross-examine accusers. Request 
reached the correct result, Judge Barnes' reasoning seenis preferable since Judge Hanscom's rationale could conceivably be stretched to allow the scattergun technique of deposing everyone who has any connection with the case on the basis that counsel might want to call them as witnesses. ${ }^{73}$ In sum, after considerable uncertainty as to whether depositions for purposes of discovery were available under FTC Rule 3.33(a) when the deponent was also a witness, ${ }^{74}$ such depositions appear to be here to stay.

A problem related to the FTC Rule 3.33(a) problem in Koppers is that of whether depositions can meet the "necessary" requirement of FTC Rule 3.33(a) on the basis that counsel is attempting to obtain information for the possible contradiction or impeachinent of a witness. ${ }^{75}$ This issue arises in two ways in FTC proceedings. First, counsel for one party may wish to gather information for the possible inpeachnient of another party's witness. Second, FTC counsel inay want to gather inforination for the possible impeachment of his own witness; impeachinent of one's own witness is allowed by FTC Rule 3.41(d) if the witness is an adverse party or an employee of an adverse party. ${ }^{76}$

The need for testimony to impeach the FTC's own witnesses was one basis of FTC counsel's ex parte ${ }^{77}$ deposition motion in General Motors. ${ }^{78}$ The admimistrative law judge noted that given the highly technical field involved, i.e., automotive engineering, ${ }^{79}$ it would be manifestly unfair to require FTC counsel to call the deponents as witnesses at trial without an opportunity to prepare for possible hostility or evasiveness on their part. ${ }^{80}$ General Motors sought modification of the order, arguing that the deletion from the 1967 revision

for Permission to Appeal, supra note 62, at 4. This argument was not discussed in the denial of the request. Denial of Request, supra note 65 , at 3.

73. However, this eventuality can be avoided by the "reasonable" requirement of FTC Rule 3.33.

74. See Gellhorn, supra note 36 , at $145-46$ n.150.

75. This basis for depositions is recognized under the federal rules. See Broadway \& Ninety-Sixth St. Realty Co. v. Loew's, 21 F.R.D. 347, 360 (S.D.N.Y. 1958). sion.

76. See 16 C.F.R. $\$ 3.41$ (d) (1974). Federal Rule 43(b) has a comparable provi-

77. FTC Rule 3.35, 16 C.F.R. $\$ 3.35$ (1974), permits such applications.

78. Application for Taking of Depositions for Purposes of Discovery at 2, General Motors Corp., No. 8907 (F.T.C., filed May 18, 1973).

79. The case involved allegedly unsubstantiated advertising claims concerning the handling of the Chevrolet Vega and the performance of the lubrication system of the Buick Opel. Complaint, General Motors Corp., No. 8907 (F.T.C., filed Dec. 11, 1972).

80. Order Granting Complaint Counsel's Request to Take Depositions of Employees of Respondent General Motors Corporation for Purposes of Discovery at 4, General Motors Corp., No. 8907 (F.T.C., May 30, 1973). 
of the Commission's rules of former FTC Rule 3.10(e)(1), ${ }^{81}$ which stated that a deposition could be used to contradict or impeach the testimony of a deponent as a witness, indicated that depositions taken primarily for impeachment purposes were no longer permissible. ${ }^{82}$ FTC counsel, opposing General Motors' motion for modification of the order, demied that impeachment was the primary purpose of the depositions but argued that even if it were, such depositions were permissible under FTC Rule 3.33(a) and that former FTC Rule 3.10(e)(1) was irrelevant because it only applied to the use of depositions at trial. ${ }^{83}$ When one reads former FTC Rule 3.10(e)(1) in context with the rest of former FTC Rule 3.10(e), it is apparent that FTC counsel's argument was correct ${ }^{84}$ and that the repeal of the rule has no bearing on the issue of the permissibility of taking depositions for impeachment. The administrative law judge found it unnecessary to rule on this precise poimt, reaffirming his earlier order allowing the depositions on the ground that the depositions were for both discovery and impeachment. ${ }^{85}$

The issue of the availability of depositions solely for impeachment was raised again in $A \& P$ when $\mathrm{A} \& \mathrm{P}$ moved to have an order allowing certain depositions certified to the Commission for interlocutory appeal. ${ }^{86}$ Opposing the motion, FTC counsel argued that the depositions were proper even assuming arguendo that they liad been requested for impeachment purposes only. ${ }^{87}$ Again the administrative law judge found it unnecessary to address this argument in denying A \& P's motion. ${ }^{88}$

Although the judges in General Motors and $A \& P$ did not base their ruhings on the permissibility of depositions for impeachment pur-

81. 28 Fed. Reg. 7088 (1973).

82. Memorandum in Support of Motion for Modification, supra note 61, at 5.

83. Opposition to Motion for Modification of Order Granting Complaint Counsel's Request To Take Depositions of Employees of Respondent General Motors Corporation for Purposes of Discovery at 2-4, General Motors Corp., No. 8907 (F.T.C., filed June 20, 1973).

84. Former FTC Rule 3.10(e) dealt with when a subpoena could "be read in evidence." 28 Fed. Reg. 7088 (1963). Subsection (1) inerely allows the introduction for purposes of impeachment. Id. Subsection (2) allows introduction, inter alia, if the deponent is dead. Id. Thus, it is clear that former FTC Rule 3.10(e) was merely meant to control the imtroduction of depositions into evidence, not the taking of depositions.

85. Order Denying Respondent's (General Motors Corporation's) Motion for Modification, supra note 65, at 3.

86. Request for Permission to Appeal, supra note 62.

87. Answer to Respondent's Application for Review at $8 \mathrm{n.11}$, The Great Atlantic \& Pacific Tea Co., No. 8916 (F.T.C., filed Aug. 6, 1973).

88. Denial of Request, supra note 65. 
poses, the Koppers opinion strongly indicates that such depositions are allowable. In Koppers, the Commission ruled in favor of depositions which were requested, in the Commission's words, "for use in cross-examination," 89 stressing the crucial nature of effective cross-examination. ${ }^{90}$ Since the need for effective impeachment of an adverse witness can be every bit as important as the right to effective cross-examination, depositions for impeachment should be treated in the same inanner as depositions for cross-examination. Thus, even without a direct holding on the precise point, the use of depositions to gather information for possible impeachment of witnesses, long a permissible basis for depositions under the federal rules, seems to be available in FTC practice.

Another important issue raised, ${ }^{91}$ but not resolved ${ }^{92}$ in $A \& P$ was whether the All-State decisions allow post-complaint discovery to be predicated on post-complaint transactions and occurrences. The complaint in $A \& P$ was issued on the basis of two pre-complaint surveys of the availability and prices of advertised items in $A \& P$ stores. ${ }^{93}$ FTC counsel then moved for authorization to depose seventeen A \& P employees concerning the results of a similar survey taken by the FTC's Bureau of Econormics in spring of 1973, after the complaint had been issued.94 A \& P argued that discovery based on the 1973 survey would violate the policy of the first All-State opimion that proper post-complaint discovery should, as the Commission stated in that opinion, "round out, extend, or supply further details for the particular transactions to be pursued." 95 A \& P characterized the requested depositions as "a new inquiry into areas unexplored until after the issuance of the coinplaimt."

In a short reply brief, FTC counsel reasoned that by labeling the discovery sought as a "new inquiry into unexplored areas," A \& P

89. 74 F.T.C. at 1573.

90. $1 d$.

91. Answer of Respondent to Motion for an Order Authorizing Depositions for Purposes of Discovery at 7, The Great Atlantic \& Pacific Tea Co., No. 8916 (F.T.C., filed Sept. 13, 1973); Reply to Respondent's Answer to Motion for an Order Authorizing Depositions for Purposes of Discovery at 1-3, The Great Atlantic \& Pacific Tea Co., No. 8916 (F.T.C., filed Sept. 19, 1973).

92. A \& $P$ reversed its position at the oral argument on the motion and agreed to grant voluntary interviews, thus rendering a ruling unnecessary. Record of Pretrial Proceedings of October 2, 1973, at 65-66, The Great Atlantic \& Pacific Tea Co., No. 8916 (F.T.C.).

93. Answer, supra note 87, at 2.

94. Motion for an Order Authorizing Depositions for Purposes of Discovery, The Great Atlantic \& Pacific Tea Co., No. 8916 (F.T.C., filed Aug. 31, 1973).

95. Answer of Respondent, supra note 91, at 5-6 (emphasis in original).

96. $1 d$. 
must have been referring to new transactions or occurrences, since the 1973 survey involved precisely the same subject matter that led to the issuance of the complaint. ${ }^{97}$ FTC counsel next pointed out that the post-complaint survey clearly could be admitted as evidence, since FTC Rule 3.15(a)(2) allows pleadings to be amended "at any time" to allow issues "reasonably withm the scope of the original complaint or notice of hearing" to be raised. ${ }^{98}$ Therefore, it was argued, the All-State limitation on post-complaint discovery must not bar discovery predicated upon events known to bear on the subject matter of the complaint at the time discovery is sought; a contrary interpretation would lead to the anomalous result that a post-complaint event could be introduced as evidence but could not be the proper object of discovery.99 Although he was not required to rule on this issue because $A \& P$ agreed to voluntary interviews, the administrative law judge indicated that he was willing to allow the depositions, ${ }^{100}$ suggesting that he may well have agreed with FTC counsel's position.

FTC counsel's argument in $A \& P$ seems well-reasoned and correct in its conclusion that discovery predicated upon post-complaint transactions is not precluded by the All-State decisions. In addition to FTC counsel's argument that FTC Rule 3.15(b) compels rejection of the requirement that post-complaint discovery always be linked to the pre-complaint investigation, such a linkage requirement must also be rejected as having no basis in the All-State language and as being contrary to the logic of the FTC rules and practice.

In All-State, the Commission was presented with a situation in which discovery was predicated upon both pre-complaint and postcomplaint events. ${ }^{101}$ However, the Commission showed no concern for this pre-complaint-post-complaint dichotony. Rather, it defined a proper post-complaint discovery order as one "aimed at obtaiming information not ordinarily obtainable before issuance of the complaint, additional details, or an extension of information as to disclosed transactions or events for which evidence is to be adduced

97. Reply, supra note 91 , at 1-2.

98. 16 C.F.R. $\S 3.15(a)(2)$ (1974). FTC Rule 3.15(b) permits the administrative law judge, "upon reasonable notice and such terms as are just," to allow service of a supplemental pleading or notice of post-complaint events which are relevant to any of the issues involved.

99. Reply, supra note 91 , at 3.

100. Record of Pretrial Proceedings, supra note 92, at 66.

101. 72 F.T.C. at 1024-25. 
in support of the complaint . ..."102 Thus, the All-State decisions clearly require only that the transaction or event upon which postcomplaint discovery is predicated be a potential evidentiary item in the proceeding, regardless of whether the event was pre- or post-complaint. This requirement obviously does not limit post-complaint discovery to those transactions or events uncovered in the pre-complaint investigation.

Moreover, demanding a limkage between post-complaint discovery and pre-complaint investigation would result in an illogical, unworkable rule. If, for exainple, the Commission received a consumer complaint alleging a transaction identical to ones alleged in a pending adjudicatory matter, FTC counsel could not conduct any necessary additional discovery, such as subpoenaing the respondent company's records as to the alleged transaction. Such a result might encourage respondents to continue allegedly illegal activies after a complaint has been issued.

In view of the foregoing arguments, it seems that discovery predicated upon post-complaint events is well-founded and will be perinitted when those events may be evidentiary items in the proceeding. Any other result would be contrary to the basic spirit of modern federal discovery and the evolving liberalization of FTC discovery.

Having reviewed the major issues which have arisen in litigation over the FTC's discovery rules, it is appropriate to turn to an analysis of the effectiveness of those rules.

\section{FTC Discovery RULES: SUCCESS OR FAILURE?}

While the FTC's discovery rules have generally received a liberal interpretation from the Commission, the question still must be asked whether those rules have been successful in practice. One strong indication that the current rules are in fact inadequate is that FTC counsel in Exxon Corp., ${ }^{103}$ a case in which the eight largest petroleum compamies have been charged with conspiracy to fix prices and to restrain competition, ${ }^{104}$ moved to have the discovery provisions of the federal rules substituted for the FTC discovery rules in that case. ${ }^{105}$ In the alternative, FTC counsel sought a

ruling that the depositions requested by any party under Section 3.33 of the Rules of Practice are "necessary for the purposes of discovery"

102. Id. at 1023-24 (emphasis added).

103. No. 8934 (F.T.C., filed July 18, 1973).

104. See Complaint, Exxon Corp., No. 8934 (F.T.C., filed July 18, 1973).

105. Motion of Complaint Counsel for Major Integrated Procedural Relief at 1, Exxon Corp., No. 8934 (F.T.C., filed Oct. 18, 1974). 
in this action, and that the "voluntary methods" requirement of Section 3.33 is met by the attempt to secure the voluntary appearance of a witness for deposition, and that all other provisions of the Rules of Practice be interpreted in a manner consistent with the policies of thorough and expeditious discovery as exemplified by the Federal Rules of Civil Procedure ...106

In denying the motion, the Commission stated that it "does not favor tailoring special rules for individual cases" but noted that revisions of the FTC discovery rules would soon be promulgated. ${ }^{107}$

The motion once again raised the issue of whether the discovery provisions of the federal rules should be adopted for FTC proceedings, an issue which has provoked reaction both pro and con in the past. ${ }^{108}$ The basic argument in favor of replacing the current FTC rules with the federal rules is the delay endemic to a discovery system where the party seeking discovery must first seek to accomplish that discovery by voluntary means and then, if unable to gain the information voluntarily, to seek compulsory process by making the affirmative showing of necessity under FTC Rule 3.33(a) for depositions or of general relevancy and reasonableness under FTC Rule 3.34(b) for subpoenas duces tecum. At that point the matter often is fully litigated with briefs, and the admimistrative law judge, perhaps after holding oral argument, issues a ruling. If the ruling is favorable to the moving party, then and only then can discovery take place. ${ }^{109}$

This process can easily take months every time discovery is sought. While such inherent delay is of itself unsatisfactory, it also has the undesirable effect of forcing the parties to rely more heavily on accomplishing discovery by voluntary methods. Because of the absence of any sanctions against the person who fails to keep interview appointments, answer questions directly, or produce documents,

106. Id.

107. Order Denying Motion for Major Integrated Procedural Relief at 1, Exxon Corp., No. 8934 (F.T.C., March 4, 1975).

108. Pro: 1 K. Davis, supra note 22, § 8.15, at 589. See also Kintner, Discovery in Administrative Adjudicative Proceedings, 16 AD. L. REv. 233 (1964); Tomlinson, supra note 31; Symposium, The Role of Discovery in Federal Trade Commission Proceedings, 21 AD. L. REV. 439 (1969).

Con: Lewis 458; cf. Note, supra note 36.

109. In $A \& P$, respondent's opposition to two sets of voluntary interviews with its employees resulted in depositions or interviews being taken up to four months after they were originally proposed to be scheduled. FTC counsel originally requested the interviews by a letter dated August 10, 1973. Motion for an Order, supra note 94, app. A. A \& P did not agree to the interviews until October 2, 1973. Record of Pretrial Proceedings, supra note 92 , at $65-66$. 
voluntary inethods are a wholly inadequate substitute for the coinpulsory processes of deposition, interrogatory, and subpoena duces tecum. In fact, a respectable argument can be made that a lawyer has an ethical obligation not to make full disclosure unless under compulsory process. ${ }^{110}$

Those who oppose adoption of the discovery provisions of the federal rules in FTC proceedings point with horror to the expense and delay which they foresee would result from the greater liberality of the federal rules. ${ }^{111}$ The basis of their fear is that, freed from the necessity of making the affirmative showings required by the current FTC rules, the parties would unduly delay the proceedings by engaging in much expensive and useless discovery. However, the delays which have occurred under the current FTC rules in the Exxon ${ }^{112}$ and $A \& P^{113}$ litigations and the large number of interlocutory appeals on discovery issues since $1967^{114}$ make it unlikely that adoption of the federal rules would cause any more delay than already exists. In addition, a switch to the federal rules would eliminate the litigation over whether the party seeking discovery has exhausted the voluntary measures and whether the affirmative showings required by FTC Rules 3.33(a) and 3.34(b) have been made. The large body of law interpreting the federal rules and attorneys' familiarity with those rules would also minimize delay.

Furtherunore, the expense and delay created by post-complaint discovery can be minimized if the case is handled properly by the administrative law judge from the outset. The Manual for Complex Litigation $^{115}$ can be used to define the issues at an early pre-trial conference and to confine discovery within the boundaries set by the defined issues. If this is done effectively, the benefits of the federal rules' party-oriented discovery approach, whereby the judge is involved only as a last resort, can be realized while minimizing the risk that the parties will abuse the discovery procedures and delay the litigation by inquiring into issues only tangentially related to the case. Of course, when a case like United States $v$. International Business Machines Corp., ${ }^{116}$ an antitrust case which involved over a million documents in discovery, or Exxon comes along, the anount of dis-

110. See ABA Code of Professional Responsibirrty EC 7-19, EC 7-27 (1969).

111. See Lewis 458-59; Mezines \& Parker, supra note 34, at 60.

112. See Motion of Complaint Counsel, supra note 105, at 2-3.

113. See note 109 supra.

114. See Lewis 458.

115. Commerce Clearing House, Manual for Complex Litigation (1973).

116. No. 69 Civ. 200 (S.D.N.Y., filed Jan. 17, 1969). 
covery and the length of the pre-trial periods are going to be enormous under any set of rules consistent with due process. But in the run-of-the-mill case, FTC or otherwise, post-complaint discovery under the federal rules is unlikely to result in undue delay or expense, especially if the issues have been properly narrowed. ${ }^{117}$

\section{CONCLUSTON}

Since 1961, the FTC has inade great strides in liberalizing its discovery procedure. There has, however, been a large amount of time-consuming litigation since 1967 over the meaning of the discovery provisions of the FTC Rules of Practice. Moreover, the fact that the current FTC rules inake every requested deposition and subpoena the likely object of litigation has resulted in many preliminary delays and interlocutory appeals of discovery orders. These factors mitigate heavily in favor of the adoption by the FTC of the discovery provisions of the Federal Rules of Civil Procedure, and it is to be hoped that the new discovery rules forthcoming from the FTC will closely track the federal rules.

117. See W. GLASER, supra note 16 , at 177 . 